VOL. 3

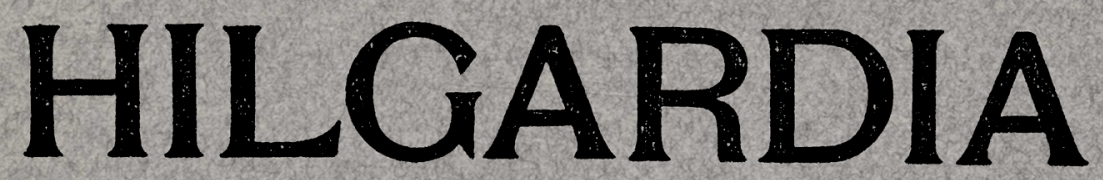

A Journal of Agricultural Science

PUBLISHED BY THE

California Agricultural Experiment Station

\title{
CONTENTS
}

Fumigation with Calcium Cyanide Dust

H. J. QUAYLE

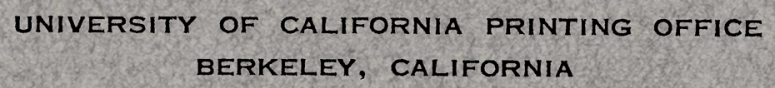




\title{
EDITORIAL BOARD
}

\author{
E. D. MERRILL, Sc.D.
}

J. T. Barrett, Ph.D.

Plant Pathology

F. T. Bioletti, M.S.

Viticulture

W. H. Chandler, Ph.D.

$$
\text { Pomology }
$$

R. E. Clausen, Ph. D.

Genetics

H. E. Erdman, Ph.D. Agricultural Economics

H. M. Evans, A.B., M. D.

Nutrition

G. H. Hart, M. D., D.V.M. Animal Husbandry

D. R. Hoagland, M.S.

Plant Nutrition

A. H. Hoffman, E.E. Agricultural Engineering
W. L. Howard, Ph. D.

Pomology

H. A. Jones, Ph.D.

Truck Crops

W. P. Kelley, Ph.D.

Chemistry

W. A. Lippincott, Ph.D.

Poultry Husbandry

C. S. Mudge, Ph. D.

Bacteriology

H. J. Quayle, M.S.

Entomology

H. S. Reed, Ph.D.

Plant Physiology

W. W. Robbins, Ph.D.

Botany

F. J. Veihmeyer, Ph.D.

Irrigation 


\title{
HILGARDIA
}

\author{
A JOURNAL OF AGRICULTURAL SCIENCE \\ PUBLISHED BY THE
}

CALIFORNIA AGRICULTURAL EXPERIMENT STATION

VOL. 3

APRIL, 1928

No. 8

\section{FUMIGATION WITH CALCIUM CYANIDE DUST ${ }^{1}$}

H. J. QUAYLE2

\section{INTRODUCTION}

When hydrocyanic acid was first used for the fumigation of citrus trees in California in $1886,{ }^{(1,2,3)}$ potassium cyanide, KCN, was the material used. Potassium cyanide continued to be used until 1909, when it was replaced by sodium cyanide, NaCN. Sodium cyanide had been used for industrial purposes, but probably because of the sodium chloride usually present and the consequent decomposition of hydrocyanic acid gas, it was slow in coming into use for plant fumigation. Sodium cyanide was first suggested by Lounsbury ${ }^{(4)}$ for plant fumigation; the effect of the presence of $\mathrm{NaCl}$ on the evolution of the gas was indicated by Newell, ${ }^{(5)}$ and Woglum ${ }^{(6)}$ demonstrated its practical use for citrus fumigation when free from the impurity $\mathrm{NaCl}$. In both of these cyanide salts hydrocyanic acid gas is evolved very slowly by simple contact with the atmosphere, so that it is necessary to add sulfuric acid and water to secure a sufficiently rapid generation.

\section{METHODS OF FUMIGATION}

The first experiments in hydrocyanic acid fumigation for citrus trees involved the use of a generator outside of the tent. This apparatus soon gave way to earthenware pots which were placed under each tree, and this method of generation was followed without change for twenty-seven years. In 1913 William Dingle designed a portable

1 Paper No. 171, University of California, Graduate School of Tropical Agriculture and Citrus Experiment Station, Riverside, California.

2 Professor of Entomology in the Citrus Experiment Station and Graduate School of Tropical Agriculture and Entomologist in the Experiment Station. 
generator which used a solution of sodium cyanide. The addition of acid to the solution of cyanide resulted in instantaneous generation of the gas, which was conducted by its own pressure through a hose from the generator to the tent. Portable machines (drawn by a horse) were in successful use from 1913 to 1918 . In 1916 Dingle demonstrated the practical use of hydrocyanic acid in liquid form for citrus fumigation, and this method is very largely used in California at the present time.

\section{“A” CALCIUM CYANIDE ${ }^{3}$}

Another form of cyanide in which cyanogen is combined chiefly with calcium became available about 1916 . This compound, $\mathrm{Ca}(\mathrm{CN})_{2}$, has served as the source from which liquid hydrocyanic acid has been manufactured by one of the plants built for the purpose in southern California. "A" calcium cyanide is formed by fusing calcium cyanamid, $\mathrm{CaCN}_{2}$, with sodium chloride. In crude form it occurs as thin gray flakes. It contains from 27 to 30 per cent HCN. The chief impurities are sodium chloride and calcium carbide.

Use in Powdered Form.-In June, 1922, it was learned that crude calcium cyanide in flake form when placed in the burrow of rodents gave off hydrocyanic-acid gas with sufficient rapidity to kill them; it thus occurred to the writer that if these flakes were ground into a fine powder the gas might be given off rapidly enough to be applicable to citrus fumigation, ${ }^{(7)}$ provided, furthermore, that the residue-since the material would have to be blown onto the tree-would be harmless. Consequently the manufacturers were asked to have prepared a small quantity of the crude flakes in powdered form. The material was first tried by dusting a few small citrus trees without covers, to determine the effect on the foliage. Later the powdered cyanide was blown under tented citrus trees by means of an ordinary hand-dusting machine. The results of the first tests were satisfactory, both in kill of scale insects and in lack of injury to the tree. Thirty orange trees were thus fumigated in August, 1922. ${ }^{(8)}$ The next series of experiments, carried on in October, when a rain immediately followed, resulted in considerable injury to lemon trees. Experiments which followed during the next three or four months indicated that

3 Two different forms of calcium cyanide will be discussed in this paper. One will be designated as " $\mathrm{A}$ ", calcium cyanide and the other as " $\mathrm{C}$ " calcium cyanide. "C"' calcium cyanide, unless otherwise indicated, will be understood to contain 30 per cent $\mathrm{HCN}$. Another grade of this cyanide containing 50 per cent HCN will be included in some of the experiments and this will be designated as " $\mathrm{C}$ ", calcium cyanide (50 per cent). 
atmosopheric moisture was the limiting factor in the use of this material for fumigating citrus trees, and more particularly lemon trees, in California.

Experiments in Australia.-In March, 1923, the writer had the privilege of continuing experiments on this method of fumigation in Australia. ${ }^{(9)}$ Between 200 and 300 trees on six different farms were successfully fumigated in these experiments when the method was adopted commercially. The commercial fumigation continued successfully until the winter rains began early in May, when injury to the trees again occurred as it had in California.

Experimental work at Leeton, New South Wales, was carried on with a temperature range of from 55 degrees to 80 degrees $\mathrm{F}$ and a relative humidity range of from 37 per cent to 55 per cent. The climate in this area is similar to that of Tulare County, California, where, so far as the few tests have shown, fumigation by the same method may be carried on with safety to the tree. The dust method has practically replaced the older methods of fumigation in Australia, where about 300,000 citrus trees were so fumigated last year. The method has been extended also into areas near the coast having a higher humidity, such as at Lismore, ${ }^{(10)}$ and Lisarow and Gosford. ${ }^{(11,12)}$

Injury to Citrus Trees.-Lemon trees were more seriously injured than orange trees. It is well known that the lemon tree, Citrus limonia Osbeck, is more resistant to hydrocyanic acid gas than the common or sweet orange, Citrus sinensis Osbeck, the sour or Seville orange, Citrus aurantium Linn., the mandarin group, Citrus nobilis Lour., and the pummelo, Citrus maxima (Burm.) Merrill. It is a curious fact, however, that in the case of fumigation with the form of calcium cyanide under discussion, the lemon is much more susceptible than the other species of Citrus. It would seem logical to conclude that this difference must be due to the residue of dust left on the tree or to some product aside from HCN given off from the residue. The definite cause of this greater injury to the lemon is not as yet fully ascertained. Injury is most likely to occur when there is considerable atmospheric moisture, roughly, above 60 or 70 per cent relative humidity.

The injury is also different in nature from that of ordinary HCN fumigation, particularly as regards the fruit. Instead of definite pits occurring on the fruit as with HCN gas, when the dust is applied the entire upper surface of the lemon may be uniformly burned. Pitting, in ordinary fumigation, may occur on the under as well as 
the upper side of the fruit. The difference in location further supports the belief that the dust residue is responsible for the injury. If it were an excess of HCN gas given off in immediate contact with the dust, then the orange should show more injury than the lemon, as it does in other methods of fumigation.

In addition to the fruit injury, a heavy leaf drop may also occur. The same type of injury may occur with the orange but to a less marked extent.

Recent reports from Australia indicate that injury to the lemon is the chief drawback to the dust method of fumigation when the weather conditions are not favorable. In Australia, however, the lemon constitutes but a small fraction of the citrus acreage.

Reasons for Investigating the Possibilities of Dust Fumigation.The original purpose of simply grinding crude calcium cyanide into a fine powder and blowing it under a tented citrus tree was to obviate the necessity of having this material go through an expensive process in order to produce liquid $\mathrm{HCN}$. If such material proved satisfactory it should reduce the cost of fumigation. The manufacture of liquid $\mathrm{HCN}$ requires a plant of considerable magnitude, and the parts in contact with the chemicals must be replaced practically every year. In addition to the cost, the question of safety to the operators is involved. Liquid HCN is a very dangerous material to handle, and all of the fatalities which have resulted in connection with citrus fumigation have occurred since the adoption of the liquid method. The liquid cannot be transported in the usual containers except by truck and it cannot be stored for any great length of time. Special precautions, such as icing, must be taken to keep the material cool in hot weather. These disadvantages would be avoided if dust fumigation should prove to be satisfactory.

Present Uses of Cyanide-Dust Fumigation.-In addition to citrus fumigation, cyanide-dust fumigation is now extensively practiced against rabbits ${ }^{(13,14,20)}$ in Australia, for the fumigation of greenhouses, ${ }^{(15,16)}$ for dwellings, ${ }^{(17)}$ storehouses, and railroad cars, and for the dusting of plants in the open (without covers) for several insect pests.

\section{"C" CALCIUM CYANIDE}

In these tests dust fumigation of citrus trees was of chief interest. Further work with the material thus far discussed was, therefore, abandoned in 1924 because there was too much danger of injuring citrus trees under the climatic conditions prevailing in southern California. 
The next procedure was to try to incorporate pure liquid HCN into powdered material that would be inert so far as the tree was concerned. Such materials as hydrated lime, calcium carbonate, talc, diatomaceous earth, kaolin, sulfur, and several others, were tried, but given up because of the decomposition of $\mathrm{HCN}$ or the increased cost as compared with the liquid $\mathrm{HCN}$ alone, which was already in satisfactory use.

Early in the fall of 1925 a small quantity of another form of dry calcium cyanide was delivered to the writer for determination of its possibilities for citrus fumigation. Tests were first made to determine its effect on citrus foliage. It was blown onto citrus trees enclosed in a tent; some of these trees were sprayed with water before and some after the fumigation. No injury occurred under these conditions, and the material was thought to be of sufficient importance to justify resuming work on the dust method of fumigating citrus trees.

In the manufacture of " $C$ " calcium cyanide any percentage of $\mathrm{HCN}$ up to a certain maximum may be incorporated. The grade discussed here contains 30 per cent of HCN. A grade containing 50 per cent of HCN is also manufactured. The latter has not been used thus far for citrus fumigation, but it is included in some of the experiments described below. " $\mathrm{C}$ " calcium cyanide is manufactured by combining liquid HCN with calcium carbide. ${ }^{(18) 4}$

" $\mathrm{C}$ " calcium cyanide is in a very fine state of division and is of a light brown color. The color is due to a slight polymerization that occurs, and this apparently increases as the amount of water used in the manufacture increases. Hydrocyanic acid gas comes off from the surface of the material rapidly enough to ignite. When the surface has sealed over, the gas is prevented from coming from below, but it will ignite again if a new surface is exposed.

Atmospheric moisture in contact with the cyanide produces hydrocyanic acid according to the following reaction:

$$
\mathrm{CaH}_{2}(\mathrm{CN})_{4}+2 \mathrm{H}_{2} \mathrm{O} \rightarrow \mathrm{Ca}(\mathrm{OH})_{2}+4 \mathrm{HCN} \text {. }
$$

4 In the article referred to the following reactions are given:

$\mathrm{CaC}_{2}+2 \mathrm{H}_{2} \mathrm{O}=\mathrm{Ca}(\mathrm{OH})_{2}+\mathrm{C}_{2} \mathrm{H}_{2}$.

$\mathrm{Ca}(\mathrm{OH})_{2}+2 \mathrm{HCN}=\mathrm{Ca}(\mathrm{CN})_{2}+\mathrm{H}_{2} \mathrm{O}$

A slight amount of water (about 2 per cent calculated on the weight of the carbide) is added as a catalyst. The author states that "It appears that the reaction is not exactly in accordance with the equations given above, but rather may be summed up as

$$
\mathrm{CaC}_{2}+4 \mathrm{HCN} \rightarrow \mathrm{Ca}(\mathrm{CN})_{2} .2 \mathrm{HCN}+\mathrm{C}_{2} \mathrm{H}_{2}
$$

or in reality this reaction may be entirely analogous to the formation of ealcium bicarbonate, i.e., the compound formed may be $\mathrm{CaH}_{2}(\mathrm{CN})_{4}$.", 


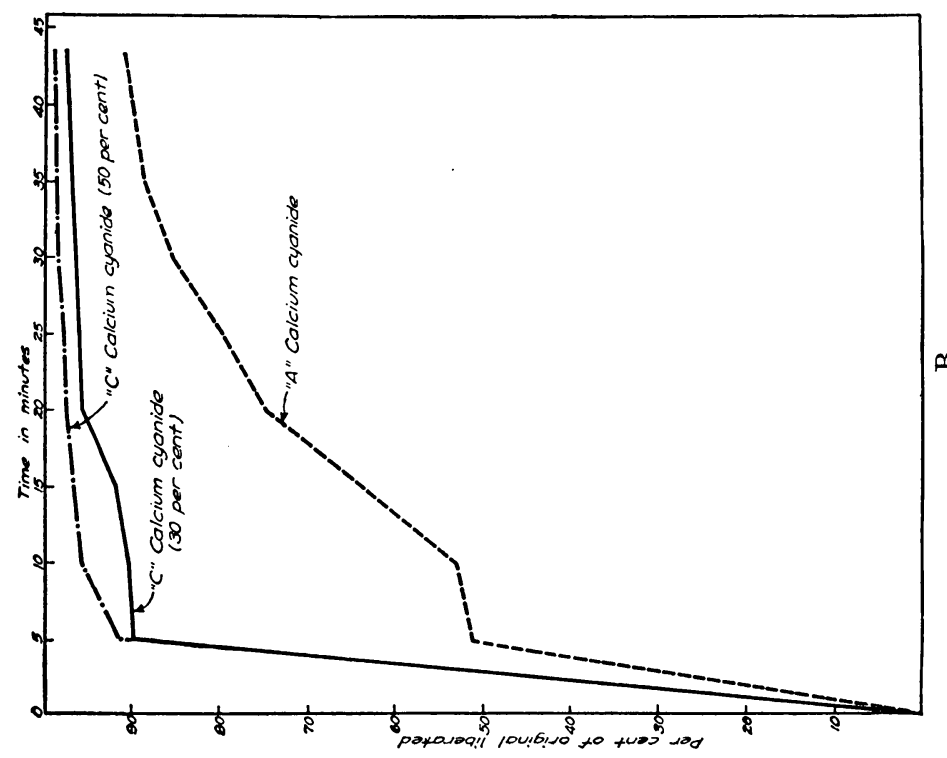

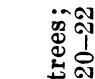
E के : 堙 索

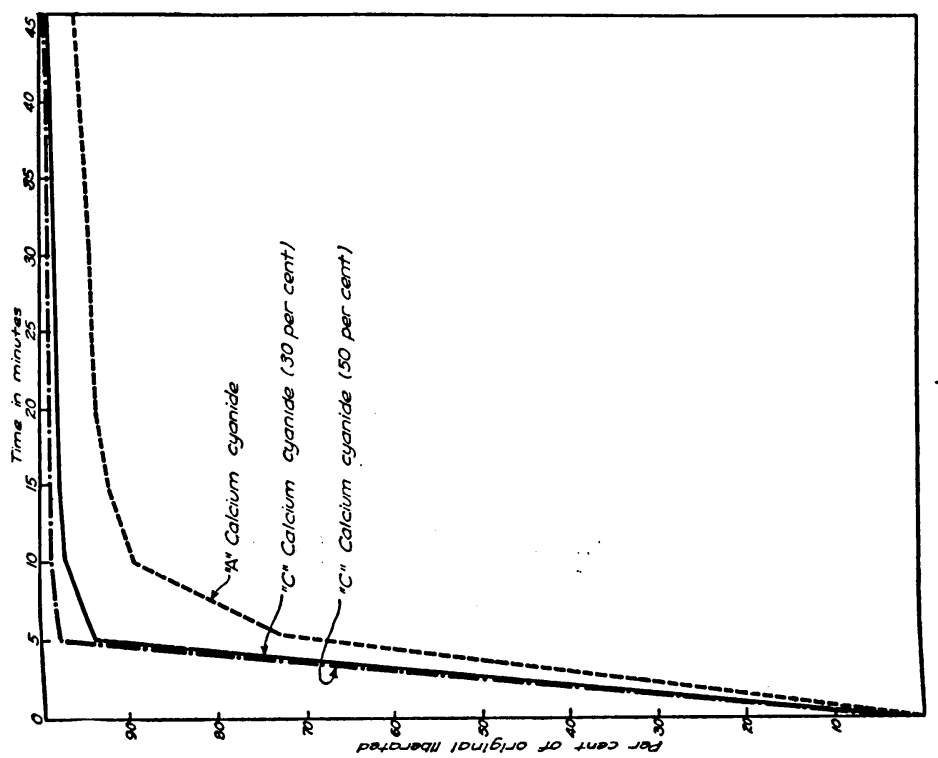

骂

.

쿵

눙

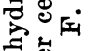

4⿻ำ

a 9 i

的

궁항

क

प山木

욜

중

है

-i 일

का

点击

4 
Practically all of the $\mathrm{HCN}$ will be liberated when the material is laid down in thin layers; the thinner the layer, obviously, the more rapid the evolution of the gas. This is the system followed in fumigating greenhouses and dwellings. For the purpose of this discussion, however, we are concerned only with the method followed in fumigating citrus trees, which consists of blowing the material under the tent by means of a dust blower. This method results in a more rapid evolution of the gas because the particles are separated and hence in more immediate contact with the moisture in the air. Blowing calcium cyanide dust into the air is a method more nearly standardized than laying the material on the floor, because it is impossible to lay down uniform layers.

\section{RATE OF EVOLUTION OF HCN GAS}

The rapidity of evolution of the gas when the cyanide dust was blown under a form tree ${ }^{5}$ was determined by collecting the residue on papers at different intervals and analyzing it for the percentage of $\mathrm{HCN}$ remaining.

The graph, figure 1A, shows the evolution of HCN gas from "A" calcium cyanide, " $\mathrm{C}$ " calcium cyanide, and " $\mathrm{C}$ " calcium cyanide (50 per cent), at temperatures of 71 degrees to 74 degrees $F$ and relative humidity of 57 to 58 per cent. At the end of 5 minutes 72.7 per cent of the HCN was liberated from "A," 93.2 per cent of the HCN from "C," and 97 per cent of the HCN from "C" (50 per cent). At the end of 10 minutes 89 per cent of the $\mathrm{HCN}$ was liberated from "A," 96.4 per cent from "C," and 98 per cent from "C" (50 per cent). At the end of the 45 -minute period 95.8 per cent of the HCN in " $A$ " was liberated, 99 per cent of the HCN from " $\mathrm{C}$ " and 99.1 per cent of the HCN from "C" (50 per cent).

The same experiment was also carried out (figure 1в) with a much lower humidity, from 20 to 22 per cent as against from 57 to 58 per cent in the first determinations. The temperature was not greatly different. Thus far no difference in the rate of evolution of the gas corresponding to difference in temperature, has been noted within the range of temperature at which commercial citrus fumigation is practical, or between 40 degrees and 80 degrees $\mathrm{F}$. Referring to figure $1_{\mathrm{B}}$, at the end of 5 minutes, 50.8 per cent of the HCN was liberated from

5 The form tree consisted of a wooden framework built in the shape of an orange tree of ordinary size, covered by a fumigating tent. The size was 26 feet over the top, with a circumference of 31 feet. 
“A," 90.2 per cent from "C," and 91.6 per cent from " $C$ " (50 per cent). At the end of 10 minutes 52.7 per cent of the HCN was liberated from "A," 90.6 per cent from "C," and 96.0 per cent from "C" (50 per cent). At the end of the 45 -minute period 91.0 per cent of the HCN was liberated from "A," 98.3 per cent from "C," and 99.0 per cent from "C" (50 per cent).

The very low relative humidity, from 20 to 22 per cent, did not greatly retard the evolution of gas from " $\mathrm{C}$ " calcium cyanide, but it affected a marked retardation in the evolution of the gas from " $\mathrm{A}$ " calcium cyanide, although by the end of the 45 -minute period a fairly good percentage (91 per cent) had evolved. However, no commercial citrus fumigation is carried on when the humidity is as low as 22 per cent. The time of the experiment was 6 P.M. Such humidity occurs during the north winds or so-called northers in southern California.

\section{COMPARATIVE DOSAGE OF "C" CALCIUM AND LIQUID HCN}

In any new system of fumigation one of the most important questions is the matter of dosage. This point was investigated by the effect on the insects as well as the determination of concentration of gas in a fumigatorium and under tented citrus trees at different intervals, in comparison with liquid HCN. In our first experiments in the use of calcium cyanide in dust form, it was observed that it was not necessary to have the dust earry as much $\mathrm{HCN}$ as was used in liquid form to secure the same effect on the scales. This fact was explained at the time by assuming that a smaller amount of gas was necessary because the dust particles were thoroughly distributed over the tree and that the generation of gas took place from each of these particles, many of which were in close contact with the scales, and thus the potency of the gas might be increased. When the dust was simply blow on the ground or not well distributed over the tree a greater dosage was necessary. This fact tended to support the idea that the diffusion of the dust particles is important. It has also been shown that young scale insects (crawlers) when in close proximity to particles of dust cyanide in the open will be killed by the gas evolved. It kills other insects that are less resistant than scale insects in a similar manner.

When a study was made of the gas concentration under the tent it was found that the same concentration occurred when less actual 
HCN was put under the tent with the dust than with the liquid. This could be accounted for only by the fact that less gas must escape through the tent in one case than in the other. The data presented in figures 4 to 9 seem to support this contention. When the fumigation is conducted in an enclosure that does not permit any leakage, this differential in favor of the dust does not appear.

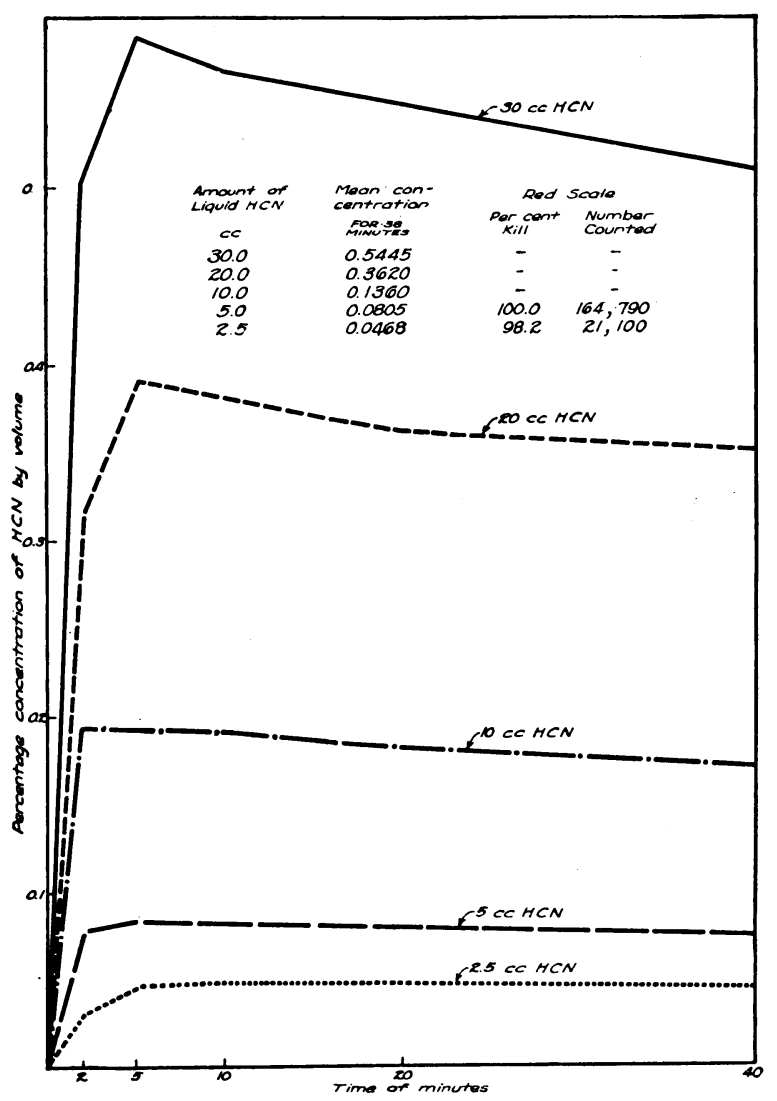

Fig. 2. The concentration of hydrocyanic acid gas at different intervals, and the mean concentration for 38 minutes, from different amounts of liquid hydrocyanic acid in a fumigatorium of 100-cu.-ft. capacity. The temperature was $62 \mathrm{~F}$ and the relative humidity 33 per cent. Compare with figure 3.

Equivalent amounts of HCN must be carried in the dust and the liquid in a gas-tight fumigatorium in order to secure the same concentration of gas within. 


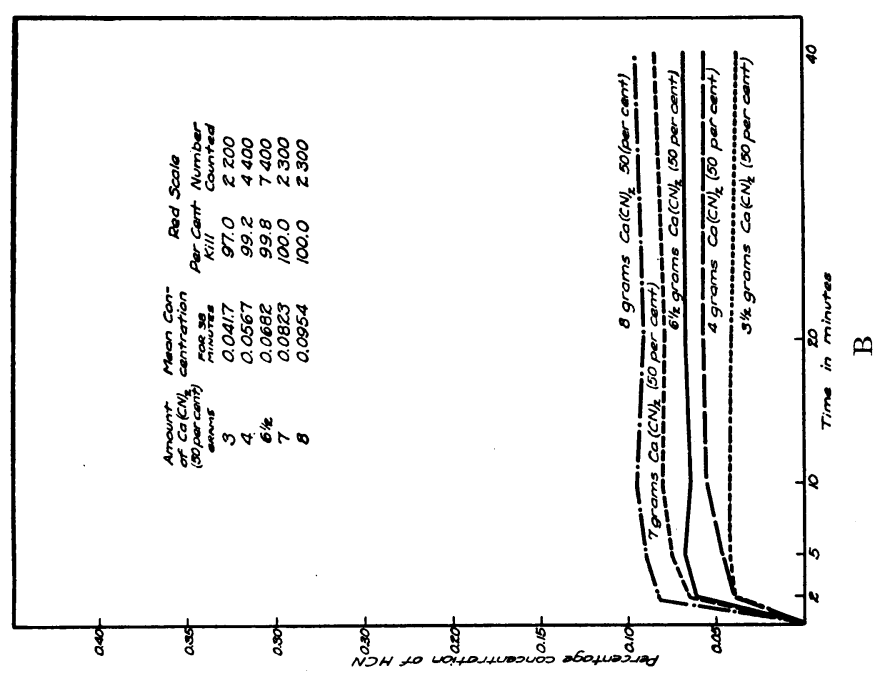

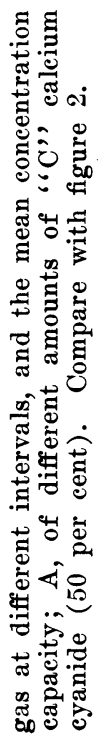

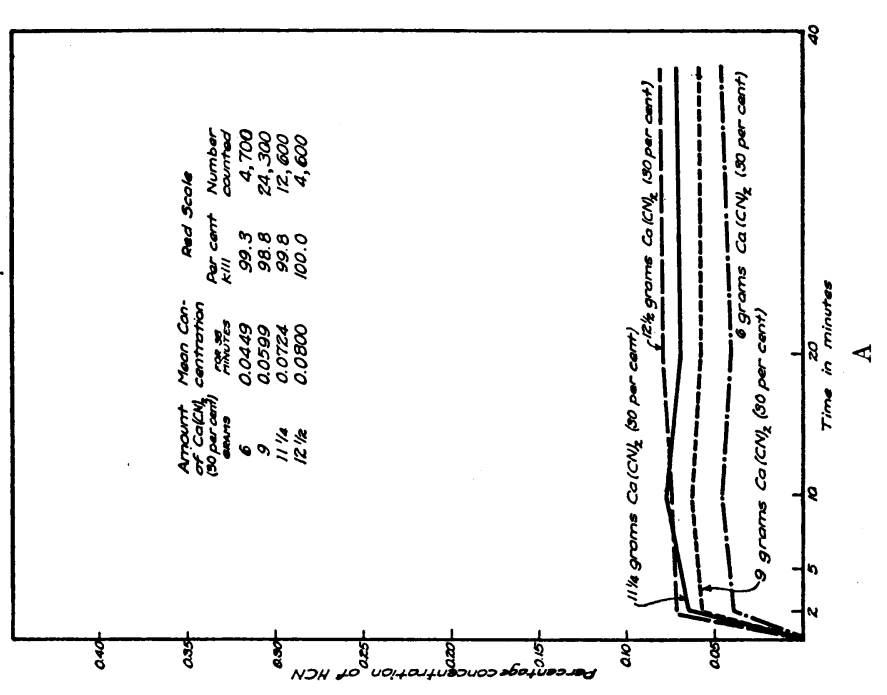

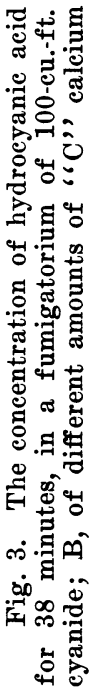


Comparisons of "C" Calcium Cyanide, "C" Calcium Cyanide (50 Per Cent) and Liquid HCN (98 Per Cent) in Fumigatorium

From the figures in table 1 it will be seen that the given amounts of the two grades of $\mathrm{Ca}(\mathrm{CN})_{2}$ carried approximately as much $\mathrm{HCN}$ as was carried in 5 ec of liquid HCN, and that the mean concentration in the percentage of $\mathrm{HCN}$ as recovered in the fumigatorium were approximately equal.

\section{TABLE 1}

Liquid HCN and "C" Calcium Cyanide; Content of HCN and Mean Concentration of HCN Gas Produced in Fumigatorium Over a 38-Minute Period

\begin{tabular}{|c|c|c|c|}
\hline Material & Amount & Amount of HCN & $\begin{array}{l}\text { Concentration of HCN gas } \\
\text { (percentage determined in } \\
\text { fumigatorium) }\end{array}$ \\
\hline $\begin{array}{l}\text { Liquid } \mathrm{HCN}_{\text {(98 per cent) }} \\
\text {....... }\end{array}$ & $5 \mathrm{cc}$ & $\begin{array}{l}\text { grams } \\
3.415\end{array}$ & 0.0805 \\
\hline $\begin{array}{l}\text { Calcium cyanide. } \\
\text { (30 per cent } \mathrm{HCN})\end{array}$ & 12.5 grams & 3.750 & 0.0800 \\
\hline $\begin{array}{l}\text { Calcium cyanide. } \\
\text { (50 per cent } \mathrm{HCN})\end{array}$ & 7 grams & 3.500 & 0.0823 \\
\hline
\end{tabular}

\section{COMPARISONS IN FIELD TESTS WITH CANVAS COVERS OVER CITRUS TREES}

Description of Methods.-Samples of HCN gas were taken from three points in the tree: one about one foot from the top of the tent, one from the center, and one one foot from the ground close to the tree trunk. Aluminum tubes (in a few cases copper tubes with shellac on the outside and inside were used) were placed at the intake positions. The ends of these tubes were loosely plugged with cotton to prevent particles of dust from entering the system in the case of $\mathrm{Ca}(\mathrm{CN})_{2}$ and also in the case of the liquid to impose the same conditions. From the other end of the metal tubes, rubber tubes conducted the gas, underneath the margin of the tent, to the aspiration bottles. 


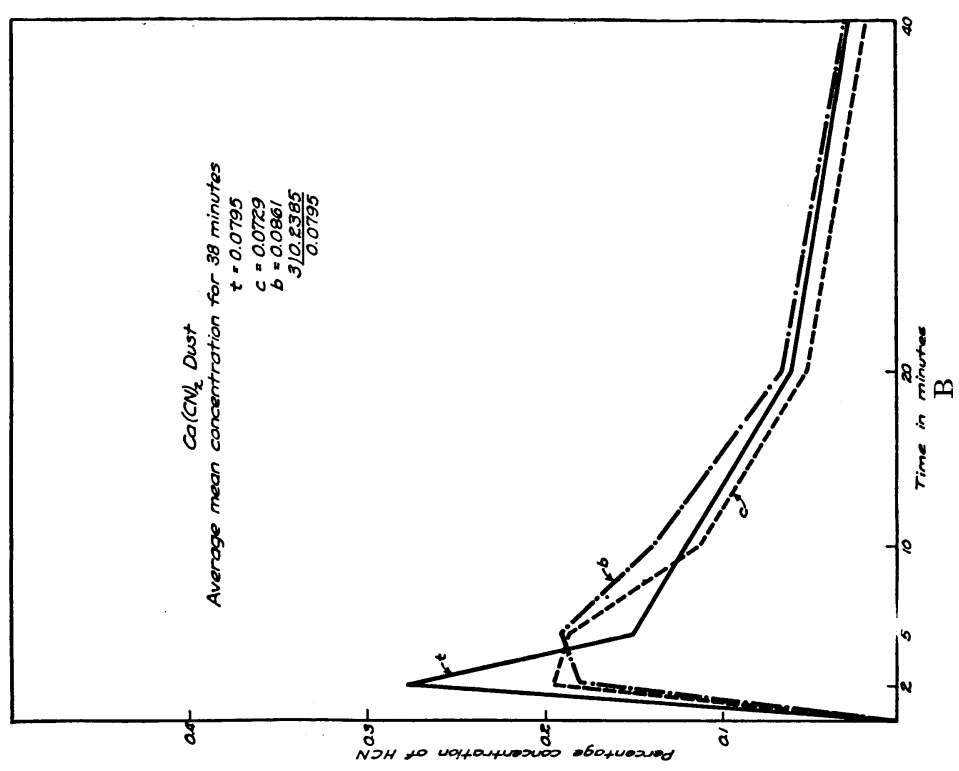

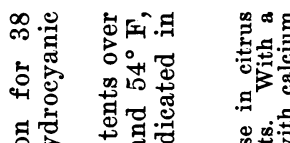

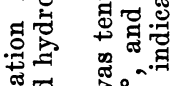

承

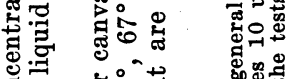

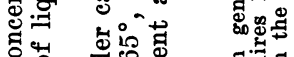

○ 羊。.

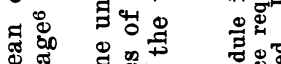

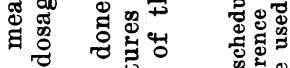

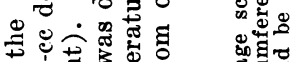

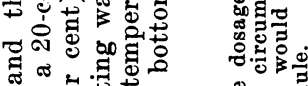

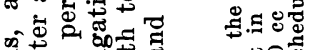

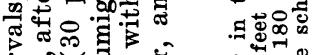

屯ै

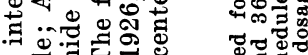

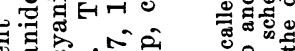

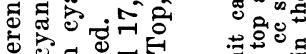

ङ

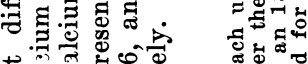

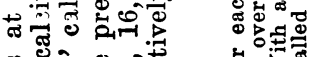

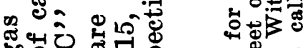

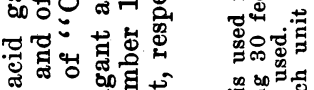

웡

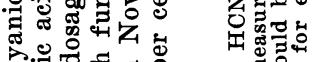

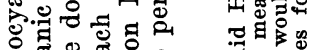

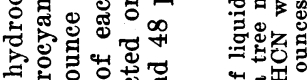

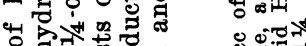

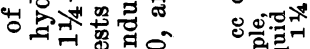

도윯

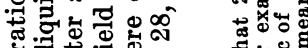

ț

क्

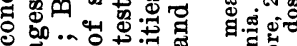

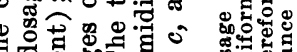

过记

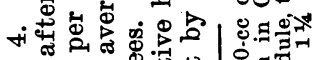

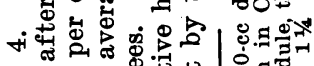

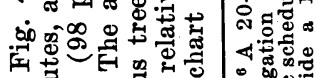

者

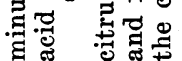

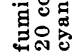




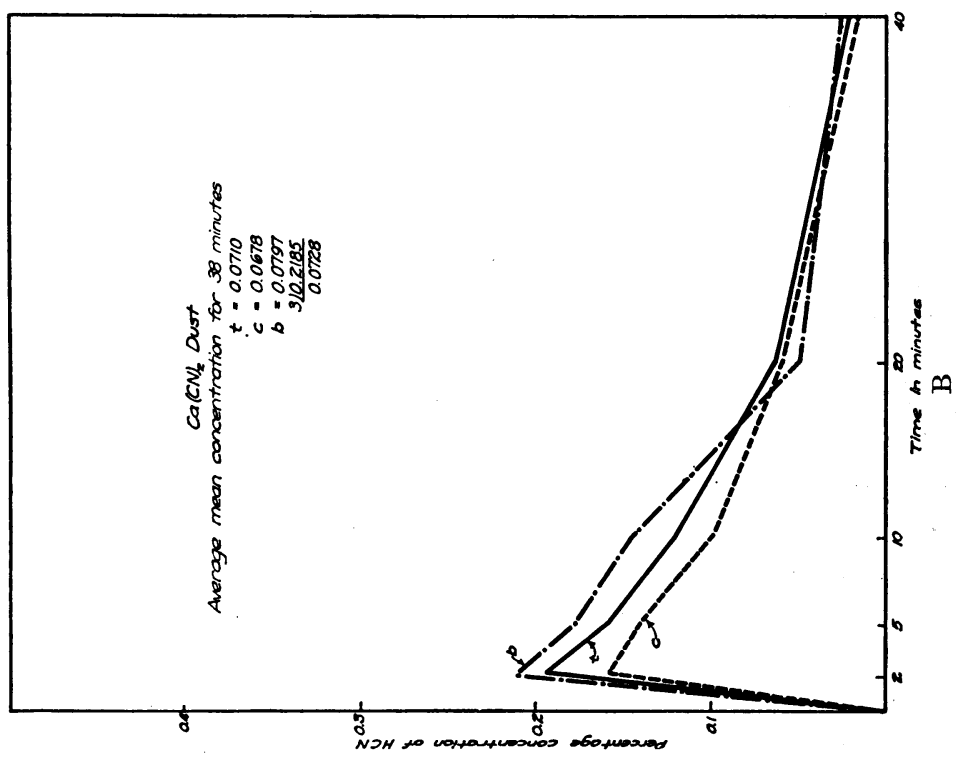

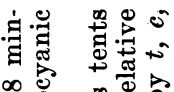

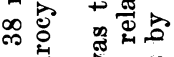

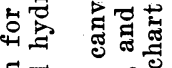

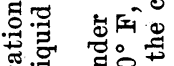
营: ङ्ञ : \% ซु 3 घ 워월 - 60.

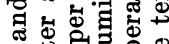
केष

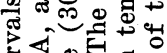
द 4 स

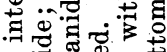

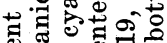

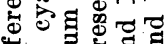
\& 局光 +. ๘

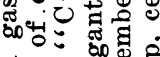

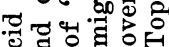
ซ 웜 T. ङ. 중 的豆

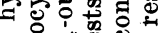
4 억 고

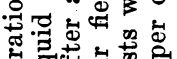

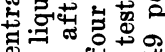
舟

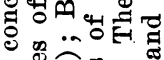
路总 至

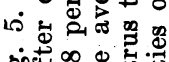

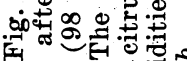

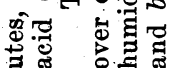


When the tubes had been installed as described, the tents were pulled over the tree, the dosage required for each tree was determined by measurement and the charge administered. Aspirations were made simultaneously from the three points in the tree at intervals of 2,5 , 10,20 , and 40 minutes from the time when the charge was completed. When liquid $\mathrm{HCN}$ and $\mathrm{Ca}(\mathrm{Cn})_{2}$ dust were compared the second tree was charged six minutes after the first, this interval being found most suitable for the manipulations and short enough to insure practically the same external conditions for the two trees. In so far as possible trees of approximately the same size were chosen. In one series of experiments the same four trees were fumigated once each night for two weeks and the liquid and dust alternated each time. The intake tubes were left in the same position so that the two methods were compared under conditions as nearly identical as possible.

To start the aspiration, the water valves $B$ and $B^{\prime}$ (fig. 6) were opened; this allowed the water to pass from $A$ to $A^{\prime}$. As the water ran out of $A$ a vacuum was created, which in turn created a vacuum in $C$; this pulled the air through $D$ from the intake position in the tree. The hydrocyanic acid taken in with the air was absorbed by the sodium carbonate in the aspiration bottle $C$. The volume of air and HCN taken out was determined by the volume of water in the aspiration can $A$ which in these tests was three liters. About one and one-half minutes were required for the water to run from $A$ to $A^{\prime}$. The aspiration being complete the two-hole stopper in $C$ was immediately removed and placed in the next bottle, and a solid rubber stopper put in its place. The water valve $B$ was closed and the rubber tube $E$ was removed from $A$ and attached to $A^{\prime}$. The positions of the aspiration cans $A$ and $A^{\prime}$ were reversed and thus the set-up was made ready for the next aspiration. Immediately after the completion of the aspiration the titrations were made in which iodine solution was used to determine the end point.

Computations.-The following computations which were used ir this work were kindly furnished by E. R. Hulbirt, of the Owl Fumigating Corporation, Azusa, California.

The essential chemical reaction involved in the titration is

$$
\mathrm{I}_{2}+\mathrm{HCN}=\mathrm{HI}+\mathrm{ICN} \text {. }
$$

A single drop of the iodine solution will cause the starch indicator to assume a dark blue color at the end point. A blank titration should be made, and from the results of this, the proper correction made in the volume of iodine solution used in each cyanide determination.

For a N/20 iodine solution, 1 ec is equivalent to 0.000675 grams of HCN. Then the percentage of HCN by volume in the aspirated sample will be 


\section{$\underline{0.000675 \times(\text { ce iodine sol. }) \times 900 \times 100}$ 3000}

where 3000 is the volume of the aspiration sample, and 900 is the volume in cubic centimeters of 1 gram of $\mathrm{HCN}$.

Both the 900 and 3000 are used without temperature and pressure corrections, for it is obvious from the formula that such corrections would cancel. Further simplified, the formula becomes $1215 \mathrm{~N} / \mathrm{ce}$ where $\mathrm{N}=$ normality of the iodine solution used, and ce $=$ the number of cubic centimeters in the aspiration sample. This becomes a constant for the same iodine solution and a fixed aspiration volume. Hence, to determine the percentage of HCN by volume in a gaseous sample, merely multiply the number of cubic centimeters of standard iodine solution used in the titration by the constant.

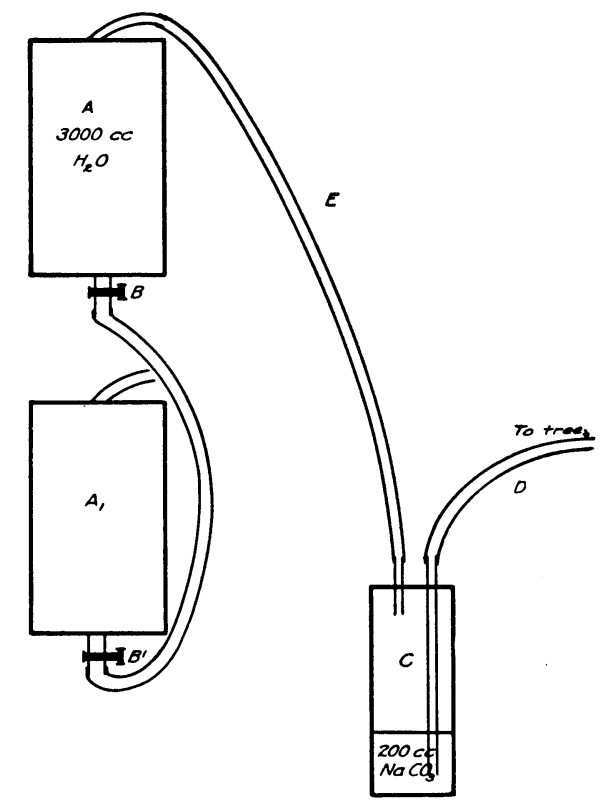

Fig. 6. Sketch showing how samples of hydrocyanic acid gas were aspirated $f$ om within the tent.

From figures 4, 5, 7, and 8 it will be noted that 11/4 ounces of "C" calcium cyanide is about the equivalent of 20 ec of liquid HCN ( 98 per cent). Also (fig. 9) that 1 ounce of " $\mathrm{C}$ " calcium cyanide is cbout the equivalent of 16 ce of liquid HCN. That is, the mean con"'sntration of gas under a tented citrus tree at night is approximately the same when the calcium cyanide and liquid are used in the ratios as given above. As judged also from the results on the scale insects these ratios are equivalent. The aspirations here given represent less than one-fourth of the total aspirations made. Each graph represents 


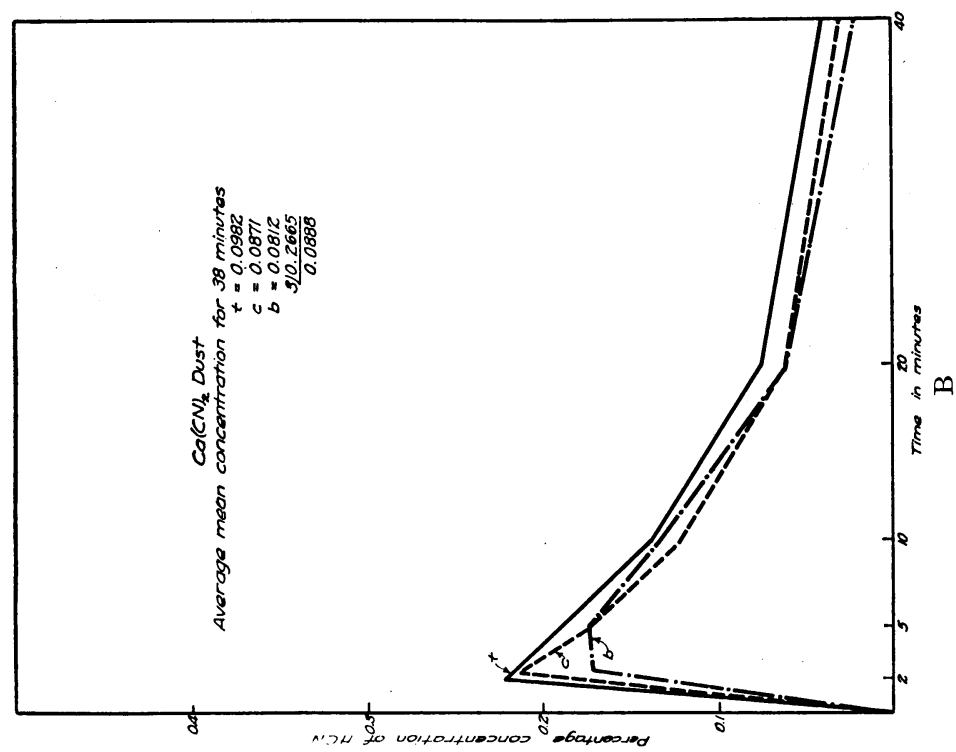

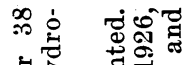

论 氙 氙

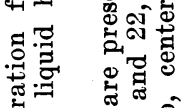

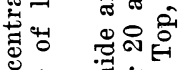

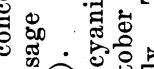

至

ซ वै. घ

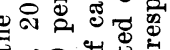
$+\infty 0$ 岁

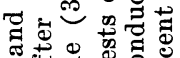
出

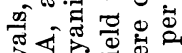
के

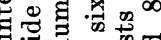

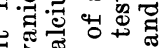

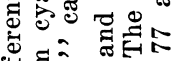

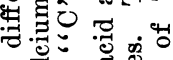
+

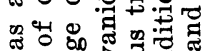
\$0

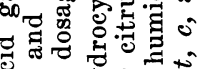
ro 0 क

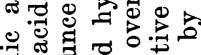
告.

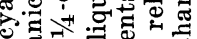
륭 क्षे

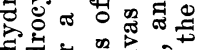

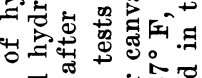

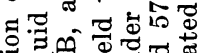

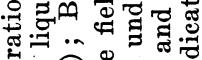
ज्ञ

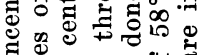

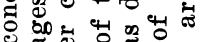

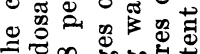
Er $\infty 0000$

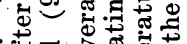

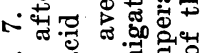
की की क्ष

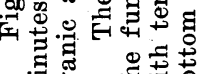




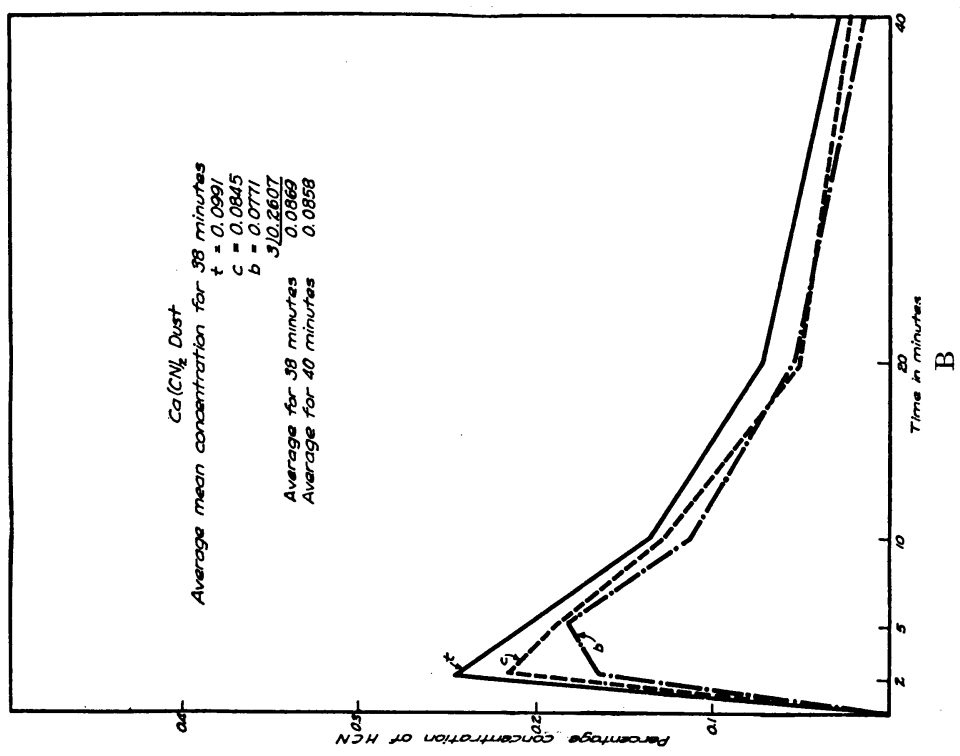

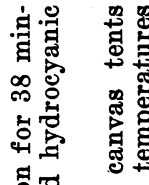

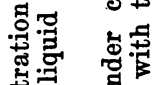

氜岁

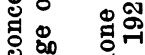

:

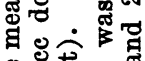

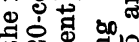

的

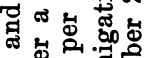

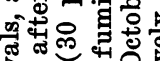

४⿻

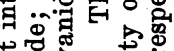

荥

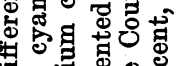

园

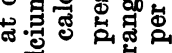

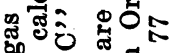

엉 경며

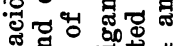

ส

踏

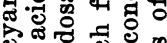

. 0.

멱

중응

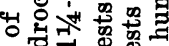

更

호

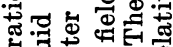

.

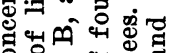

이음

o

F

잉 ప

$\infty$ 에

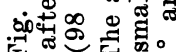

मी स से

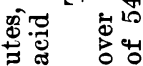




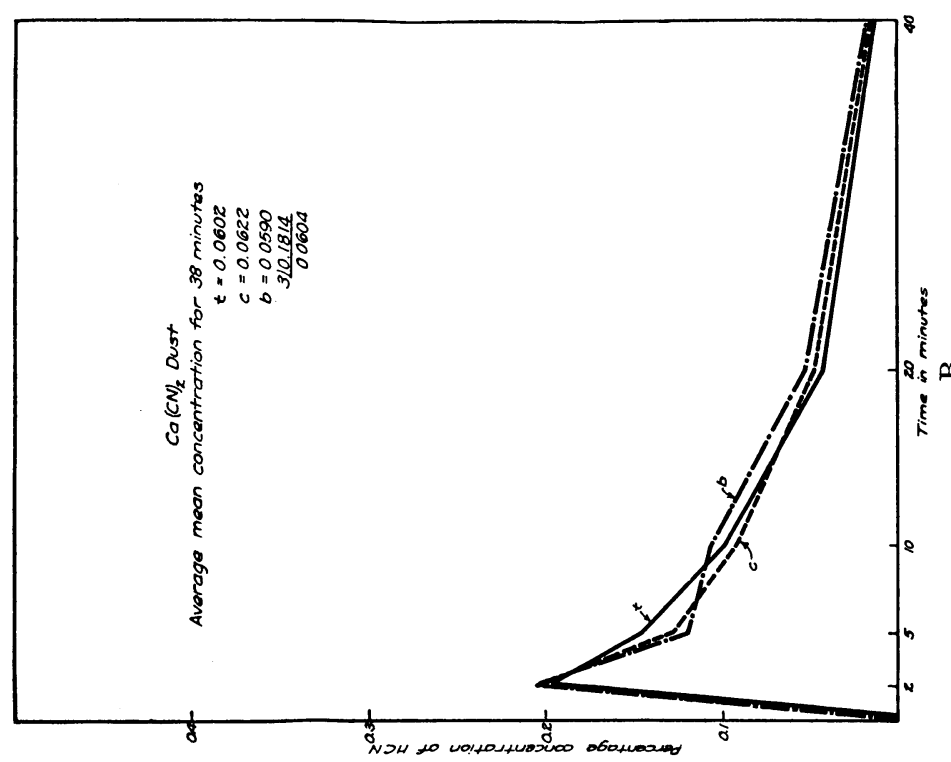

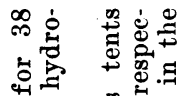

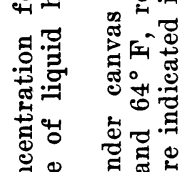
范

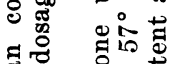

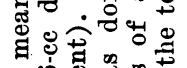

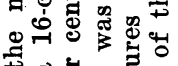
† का

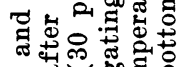
車.

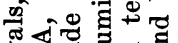
…려 过需它

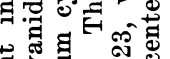

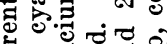

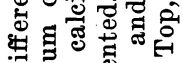

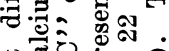

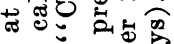

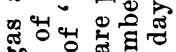
0영 .웛

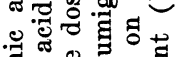
औँ 8 क्ष 今.

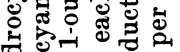
兘 क प

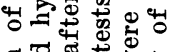

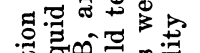

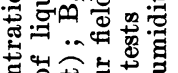

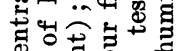

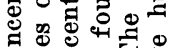

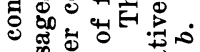

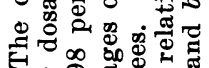
H.

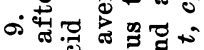

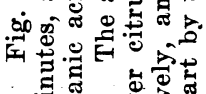

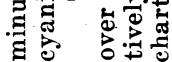


the average of a set of aspirations which were made under different conditions as to temperature and relative humidity. In every case, however, the dust and liquid cyanide were compared under the same conditions. Some determinations have been made with larger amounts, or $1 \frac{1}{2}$ ounces of calcium cyanide in comparison with 24 ec of liquid. These ratios should be equivalent so far as gas concentration is concerned, but there is some evidence tending to indicate that with high concentrations the HCN in the air may be in equilibrium

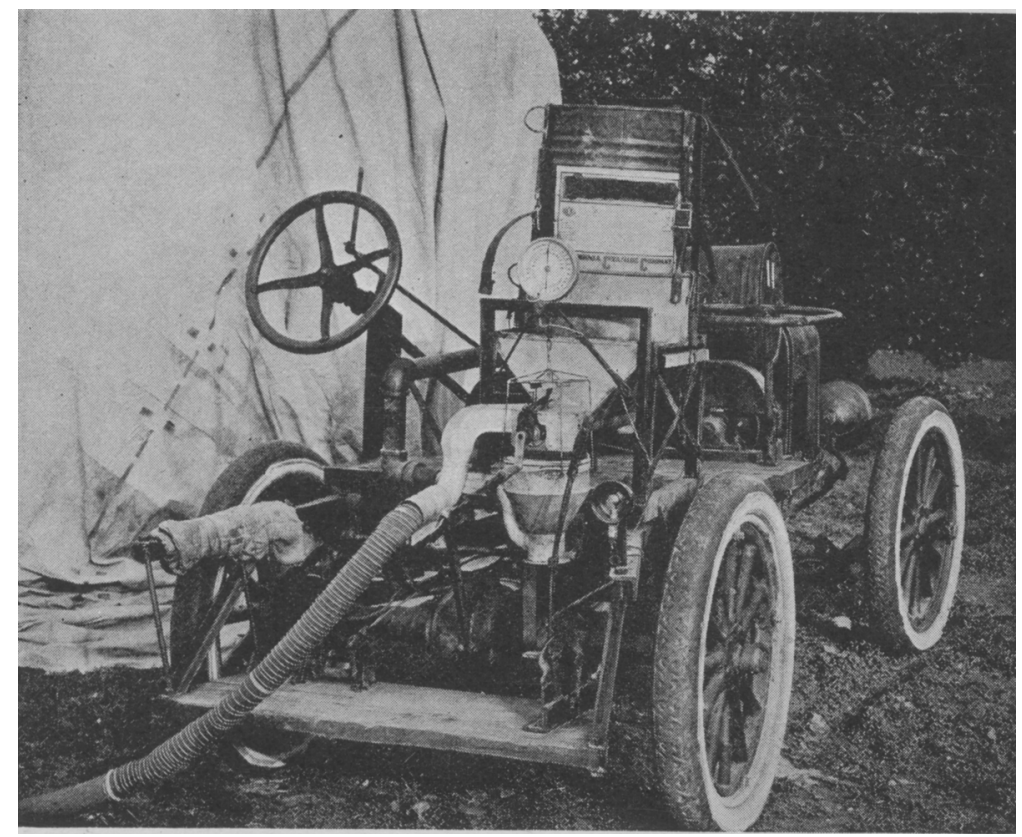

Fig. 10. Motor-power dust applicator for applying cyanide dust under tented trees.

with that in the dust and thus prevent complete evolution of the gas. The mean concentration was calculated for the most part for a 38minute interval, or from 2 minutes after the charge to 40 minutes after. The average for the concentrations at 2 minutes and at 5 minutes was multiplied by the time interval of 3 minutes. Likewise the average for 5 minutes and 10 minutes was multiplied by the 5 minute interval, and so on through the period, when the total was divided by the total time interval, or 38 minutes. Averages were obtained also for the 40-minute interval, starting from the time the charge was given; in this case one-half the concentration at 2 minutes was included and the whole divided by 40 instead of by 38 . This gave 
a slightly lower mean concentration and may be preferable to the 38-minute interval. The writer would be inclined in future work. to base the mean concentration on the full period from the time when the charge was given, which in this case would be 40 minutes.

In order to secure approximately the same gas concentration under a canvas tent as well as the same effect on insects, one should use an amount of calcium cyanide that carries about one-fourth less HCN by weight than is carried in the equivalent amount of liquid HCN. For example, 20 ce of liquid contains 13.6612 grams of $\mathrm{HCN}$; onefourth or 3.4153 grams less than this $=10.2459$ grams or approximately the amount (10.6311 grams) contained in 11/4 ounces of calcium cyanide.

Another Method of Determining Mean Concentration.-Carrying on aspirations in the field is a tedious task, and the number of trees from which tests may be made is limited. Sixty bottles are required for four trees where five aspirations are made from each of three points. In an attempt to simplify this procedure a single bottle containing $\mathrm{Na}_{2} \mathrm{CO}_{3}$ was placed in the top, another in the center, and a third at the bottom of each tree, and allowed to remain throughout the fumigation period, when they were immediately removed and stoppered. They must be suspended vertically, otherwise the surface area of the liquid in the jars will vary, and consequently the absorption of the gas will vary. While we were comparing the concentration of gas from the dust it was necessary to cover the mouths of the bottles with two or three layers of cheesecloth and this same condition was imposed on the bottles where liquid HCN was used. When a considerable amount of the dust settles on the cheesecloth, as was occasionally the case, too much gas was absorbed. The method was abandoned, therefore, in making comparisons where the dust was involved. For comparisons of the mean concentration of gas from the liquid the method seemed to work satisfactorily. It was checked with the standard aspiration method, and the results agreed fairly closely. In most of such work after the state of diffusion at different intervals is once known, the matter to be determined is the mean concentration rather than the concentration at particular intervals. Bottles containing alkaline solution so placed in the tree absorb the gas throughout the period of exposure. When these are titrated the percentage of gas can be determined and this without further calculation would represent the mean concentration. The temperature of the absorbing material makes a difference, so that the method is applicable only for a comparison of two or more trees fumigated at the same time and place. 


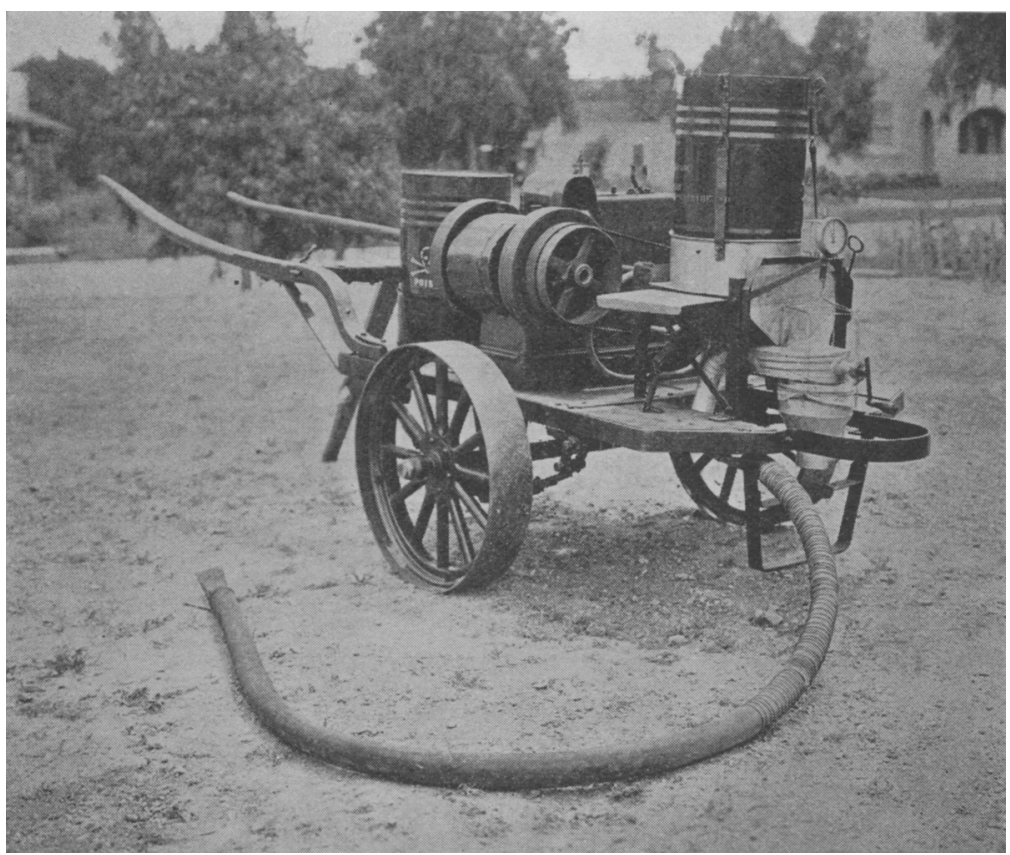

Fig. 11. Horse-drawn power dust applicator for applying cyanide dust under tented trees. A motor operating an air pump forces the material under the tent.

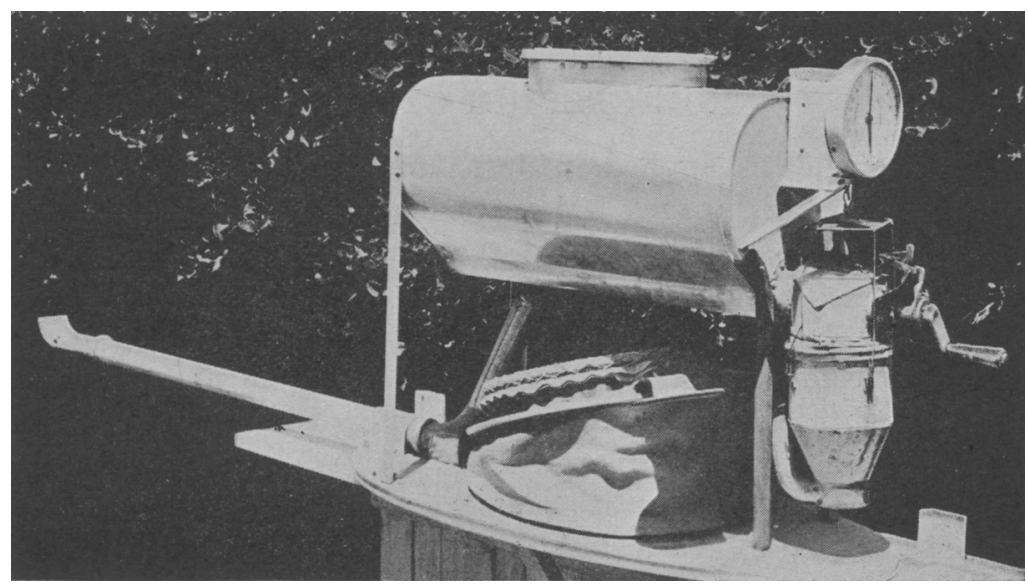

Fig. 12. Hand dust applicator for applying cyanide dust under tents or enclosures. 
TABLE 2

Summary of One Set of Field Tests

\begin{tabular}{c|c|c|c|c|c}
\hline \hline \multicolumn{3}{c|}{ Liquid HCN } & \multicolumn{3}{c}{$\mathrm{Ca}(\mathrm{CN})_{2}$} \\
\cline { 1 - 2 } $\begin{array}{c}\text { Number } \\
\text { of tests }\end{array}$ & Dosage & $\begin{array}{c}\text { Mean concentration } \\
\text { liquid HCN }\end{array}$ & $\begin{array}{c}\text { Number } \\
\text { of tests }\end{array}$ & Dosage & $\begin{array}{c}\text { Mean concen- } \\
\text { tration HCN }\end{array}$ \\
\hline & $c c$ & per cent & & ounces & per cent \\
21 & 20 & 0.0841 & 16 & $11 / 4$ & 0.0825 \\
4 & 16 & 0.0651 & 4 & 1 & 0.0604 \\
\hline
\end{tabular}

TABLE 3

Grams HCN is Given Amounts of "C"' Calcium Cyanide (30-Per-Cent HCN) AND LIQUID HCN (98 PER CENT)

\begin{tabular}{c|c|c|c}
\hline $\begin{array}{c}\text { "Cal" } \\
\text { Calcium } \\
\text { cyanide }\end{array}$ & HCN & $\begin{array}{c}\text { Liquid } \\
\text { HCN }\end{array}$ & HCN \\
\hline ounces & grams & $c c$ & grams \\
$1 / 4$ & 2.1262 & 12 & 8.1967 \\
$1 / 2$ & 4.2524 & 14 & 9.5628 \\
$3 / 4$ & 6.3786 & 16 & 10.9290 \\
1 & 8.5049 & 18 & 12.2951 \\
$11 / 4$ & 10.6311 & 20 & 13.6612 \\
$11 / 2$ & 12.7573 & 22 & 15.0273 \\
$13 / 4$ & 14.8835 & 24 & 16.3934 \\
2 & 17.0097 & 26 & 17.7596 \\
\hline
\end{tabular}

\section{DIFFUSION OF GAS UNDER THE TENT WHEN GENERATED FROM CALCIUM CYANIDE}

When cyanide is applied in dust form under a tented tree the initial diffusion of the gas is largely dependent on the manner in which the dust is distributed. If the dust is placed wholly on the ground, the bottom of the tent will carry the heaviest concentration, at least for a short period. If the dust is blown well to the top of the tree, the concentration will be greatest at this point and will remain so because of the tendency of the gas to rise. In the case of trees of small to medium size, with the machines in present use, the gas occurs in slightly greater concentration at the center and top of the tree. The aspirations also show a slightly greater concentration of gas from the dust at the end of 40 minutes than from the liquid. This may be accounted for by the fact that the gas continues to generate longer from the dust than from the liquid. 


\section{METHOD OF APPLYING CALCIUM CYANIDE DUST UNDER THE TENTED TREE}

Calcium cyanide is transported to the field in cans having a friction top which excludes the air. The friction lid is removed and a false top put in place when the container is inverted over the hopper of the machine (see fig. 10), and a sliding lid is removed to allow the material to drop into the hopper. In this way very little air comes in contact with the cyanide until it is blown under the tent. A crank operating a screw in the bottom of the hopper feeds the material into the weighing device until the proper dosage for the tree may be read on the dial. An air pump which is operated by the automobile engine (fig. 10), or by a gasoline engine (fig. 11) supplies the air which blows the charge through a large hose whose open end has been previously placed under the tent. A nozzle on the end of the hose spreads the charge and directs it upward through the tree. For small trees or where the work is not too extensive a hand machine (fig. 12) may be used. The same weighing device is installed as on the larger machine, and the foot bellows furnishes the force for distributing the charge under the tree.

\section{SUMMARY}

1. The recent production of calcium cyanide $\left(\mathrm{Ca}(\mathrm{CN})_{2}\right)$, a less stable compound than the sodium cyanide $(\mathrm{NaCN})$ or potassium cyanide $(\mathrm{KCN})$ heretofore used for fumigation purposes, has made it possible to employ a different method of fumigation which consists of simply blowing the material or putting it down in thin layers in finely divided form into an enclosure.

2. The atmospheric moisture acting on the small dust particles produces a sufficiently rapid generation of gas to make the method applicable even to citrus fumigation, where the fumigation period does not exceed one hour.

3. Two forms of calcium cyanide designated in this paper as " $\mathrm{A}$ " calcium cyanide and " $\mathrm{C}$ " calcium cyanide, are discussed.

4. "A" calcium cyanide, in powdered form, first used by the author in 1922, is largely used for citrus fumigation and for rabbits in Australia, for greenhouse and other fumigation generally, as well as for dusting in the open (without covers) for several insect pests. 
5. The investigation of "A" calcium cyanide for citrus fumigation in California was terminated in 1924 because of injury to the citrus tree.

6. In 1925 " $\mathrm{C}$ " calcium cyanide was first tried for citrus fumigation in California and the injury resulting from the residue of " $A$ " calcium cyanide was practically entirely obviated with this material.

7. "C" calcium cyanide was used in a considerable amount of commercial citrus fumigation in the state during 1926.

8. Comparisons of dosage between " $\mathrm{C}$ " calcium cyanide and liquid HCN are given; the determinations are based on the effects on insects and on the actual gas concentration under the tent at different intervals.

9. Less $\mathrm{HCN}$ is required in the calcium cyanide dust than in liquid HCN to effect the same mean concentration of gas under a canvas cover.

10. In the case of a gas-tight fumigatorium the same amount of HCN must be carried in the dust as in the liquid to give the same mean concentration within.

11. From the last two facts it is concluded that there is less escape of gas through canvas covers where the source of the gas is the dust than where the source of gas is the liquid $\mathrm{HCN}$.

12. About 25 per cent less gas is required in the dust than in the liquid. The data given indicate that $1 \frac{1}{4}$ ounces of " $C$ " calcium cyanide dust is equivalent to 20 ec of liquid $\mathrm{HCN}$, and there is approximately 25 per cent less $\mathrm{HCN}$ in this amount of the dust than there is in 20 ec of $\mathrm{HCN}$.

13. The evolution of gas from " $\mathrm{C}$ " calcium cyanide was not greatly retarded when the relative humidity was as low as 20 to 22 per cent, but this humidity did markedly retard the evolution of gas from "A" calcium cyanide. The evolution of gas from both cyanides seemed to be independent of temperature within ordinary fumigation limits, that is, between 40 and 80 degrees $\mathrm{F}$. 


\section{LITERATURE CITED}

1 Morse, F. W.

1887. The use of gases against scale insects. California Exp. Sta. Bul. 71:1.

2 COQuiletT, D. W.

1888. Report on the gas treatment for scale insects. U. S. Dept. Agr., Ann. Rept. 1887:123-142.

3 Riley, C. V.

1887. The scale insects of the orange in California, and particularly the

Icerya or fluted scale. U. S. Dept. Agr., Div. Ent., Bul. 15:21-22.

4 Lounsbury, C. P.

1902. Cyanide gas remedy for scale insects. Cape Good Hope Colony Dept. Agr., Pamphlet 11:1-27.

5 Newell, WM.

1905. An inquiry into the cyanide method of fumigation nursery stock.

Georgia State Board Ent. Bul. 15:1-24.

6 WOGLUM, R. S.

1911. The value of sodium cyanide for fumigation purposes. U. S. Dept. Agr., Bur. Ent., Bul. 90: 83-90.

7 KNIGHT, HUGH

1923. Dust fumigation. California Citrograph, 8:322-324.

8 QUAYLE, H. J.

1923. Calcium eyanide dust as an insecticide. Jour. Econ. Ent., 16:327-328.

9 McKeown, KeIth C.

1923. Fumigation of Citrus trees-Potassium cyanide method superseded - Successful tests with calcium cyanide. Fruit World of Australasia, 24:288.

10 Allen, W. J., and W. B. Stokes

1924. Calcium cyanide for Citrus fumigation. Agr. Gazette N. S. W., 35:664-666.

11 Arthur, J. M., and T. H. Harrison

1926. Calcium cyanide dust for fumigation of Citrus trees. Agr. Gazette N. S. W., 37:245-248.

12 Brown, W. H.

1926. Dust fumigating Citrus trees. Agr. Gazette N. S. W., 37:927-928.

13 Henry, Max

1923. The use of calcium cyanide as an agent in the destruction of rabbits. Agr. Gazette N. S. W., 34:485-488. 
14 Tillyard, R. J.

1925. Destruction of rabbits by calcium cyanide dust. New Zealand Farmer, Auckland, Mar. 2.

15 GuYton, T. L.

1925. Greenhouse fumigation. Pennsylvania Dept. Agr., 8(17):1-8.

16 WEIGEL, C. A.

1926. Calcium cyanide as a fumigant for ornamental greenhouse plants. U. S. Dept. Agr., Cir. 380:1-8.

17 SMith, ROGER C.

1926. House fumigation with calcium cyanide. Jour. Econ. Ent., 19:65-77. 18 MetZger, F. J.

1926. Calcium cyanide-Powdered hydrocyanic acid-A new product of manufacture. Indus. and Eng. Chem., 18:161-163.

19 QUAYLE, H. J.

1926. New material for Citrus fumigation. Calif. Citrograph, 11:296-298

20 QuAYle, H. J.

1927. Cyanide dust fumigation. Jour. Econ. Ent., 20:200-203.

21 EDDy, C. O.

1927. House fly fumigation. South Carolina Agr. Exp. Sta. Bul. 237:1-14. 
The titles of the Technical Papers of the Californta Agricultural Bxperiment Station, Nos. 1 to 20, which IIIGARDIA replaces, and copies of which may be had on application to the Publication Secretary, Agricultural Fxperiment Station, Berkeley, are as follows:

1. The Removal of Sodium Carbonate from Soils, by Walter P. Kelley and Fdward F. Thomas. January, 1923.

3. The Formation of Sodium Carbonate in Solls, by Arthur B. Cummins and Walter P. Kelley. March, 1923.

4. Effect of Sodium Chlorid and Calcium Chlorid upon the Growth and Composition of Toung Orange Trees, by H. S. Reed and A. R. O. Haas. April, 1923.

5. Citrus Blast and Black Pit, by H. 8. Fawcett, W. T. Forne, and A. I. Camp. May, 1923.

6. A Study of Deciduous Fruit Tree Rootstocks with Special Reference to Their Identification, by Myer J. Hoppner. June, 1928.

7. A Study of the Darkening of Apple Tissue, by F. I. Overholser and W. V. Cruess. Jume, 1923.

8. Effect of Salts on the Intake of Inorganic Flements and on the Buffex System of the Plant, by D. R. Hoagland and J. C. Martin. July, 1923.

9. Ixperiments on the Reclamation of Alkall Soils by Ireaching with Water and Gypsum, by P. I. Fibbard. August, 1923.

10. The Seasonal Variation of the Soll Moisture in a Walnut Grove in Relation to Fygroscopic Coeficient, by T. D. Batchelor and H. S. Reed. September, 1923.

11. Studies on the Bffects of Sodium, Potassium, and Calcium on Young Orange Trees, by H. S. Reed and A. R. O. Haas. October, 1923.

12. The Effect of the Plant on the Reaction of the Culture Solution, $\mathbf{b y} \mathbf{D}$. R. Hoagland. November, 1923.

13. Some Mutual Effects on Sofl and Plant Induced by Added Solutes, by John S. Burd and J. C. Martin. December, 1923.

14. The Respiration of Potato Tubers in Relation to the Occurrence of Blackheart, by J. P. Bennott and I. T. Baxtholomew. January, 1924.

15. Replaceable Bases in Solls, by Walter P. Kelley and S. Mivin Brown. Fobruary, 1924.

16. The Moisture Fiquivalent as Inflienced by the Amount of Soll Used in Its Determination, by $\mathbf{F}$. J. Veihmeyer, $\mathbf{O}$. W. Israelsen and J. P. Conrad. September, 1924.

17. Nutrient and Toxic Effects of Certain Ions on Citrus and Walnut Trees with Especlal Reference to the Concentration and Ph of the Medium, by II. S. Roed and A. R. C. Haas. October, 1924.

18. Factors Infitencing the Rate of Germination of Seed of Asparagus officinalis, by H. A. Borthwick. March, 1925.

19. The Relation of the Subcutaneous Administration of Iiving Bacterium abortum to the Immunity and Carrier Problem of Bovine Infectious Abortion, by George H. Fart and Jacob Traum. April, 1925.

20. A. Study of the Conductive Missues in Shoots of the Bartlett Pear and the Relationship of Food Movement to Dominance of the Apical Buds, by Frank E. Gardner. April, 1925. 